\title{
Assessing the Potential Impacts to Riparian Ecosystems Resulting from Hemlock Mortality in Great Smoky Mountains National Park
}

\author{
Scott W. Roberts · Roger Tankersley Jr. • \\ Kenneth H. Orvis
}

Received: 29 October 2007/Accepted: 9 May 2009/Published online: 4 June 2009

(C) The Author(s) 2009. This article is published with open access at Springerlink.com

\begin{abstract}
Hemlock Woolly Adelgid (Adelges tsugae) is spreading across forests in eastern North America, causing mortality of eastern hemlock (Tsuga canadensis [L.] Carr.) and Carolina hemlock (Tsuga caroliniana Engelm.). The loss of hemlock from riparian forests in Great Smoky Mountains National Park (GSMNP) may result in significant physical, chemical, and biological alterations to stream environments. To assess the influence of riparian hemlock stands on stream conditions and estimate possible impacts from hemlock loss in GSMNP, we paired hardwood- and hemlock-dominated streams to examine differences in water temperature, nitrate concentrations, $\mathrm{pH}$, discharge, and available photosynthetic light. We used a Geographic Information System (GIS) to identify stream pairs that were similar in topography, geology, land use, and disturbance history in order to isolate forest type as a variable. Differences between hemlock- and hardwood-dominated streams could not be explained by dominant forest type alone as forest type yields no consistent signal on measured conditions of headwater streams in GSMNP. The variability in the results indicate that other landscape variables, such as the influence of understory Rhododendron species, may exert more control on stream conditions than canopy composition.
\end{abstract}

\footnotetext{
S. W. Roberts · K. H. Orvis

Department of Geography, University of Tennessee,

Knoxville, TN, USA

S. W. Roberts $(\square)$

Sierra Nevada Aquatic Research Laboratory, 1016 Mt. Morrison Road, Route 1, Box 198, Mammoth Lakes, CA 93546, USA

e-mail: sroberts@lifesci.ucsb.edu; scottwrs@gmail.com

R. Tankersley Jr.

Tennessee Valley Authority, Knoxville, TN, USA
}

The results of this study suggest that the replacement of hemlock overstory with hardwood species will have minimal impact on long-term stream conditions, however disturbance during the transition is likely to have significant impacts. Management of riparian forests undergoing hemlock decline should, therefore, focus on facilitating a faster transition to hardwood-dominated stands to minimize long-term effects on water quality.

Keywords Tsuga Canadensis · Hemlock mortality · Hemlock Wooly Adelgid · Great Smoky Mountains National Park · GIS modeling · Stream temperature

\section{Introduction}

Invasive exotic pests are one of the most immediate threats to the conservation and preservation of our natural areas (Vitousek and others 1996; Vitousek and others 1997; Mack and others 2000). Exotic species have the potential to alter species composition as well as ecosystem structure and function (Castello and others 1995; Liebhold and others 1995; Ellison and others 2005). In the past century, eastern North America's forests have been significantly altered by exotic species infestations and pathogens, such as the Chestnut Blight (Anagnostakis 1987), Gypsy Moth (Liebhold and others 1995), Beech Bark Disease (Houston 1994), and Balsam Wooly Adelgid (Hollingsworth and Hain 1991). One of the most recent threats to Appalachian forests is the Hemlock Woolly Adelgid, Adelges tsugae (HWA). The HWA is currently spreading across the forests of eastern North America and causing mortality of eastern hemlock (Tsuga canadensis) and Carolina hemlock (Tsuga caroliniana) (McClure 1991). Hemlock decline and morality caused by HWA infestation has already occurred in the mid- 
Atlantic and northeastern United States (Orwig and others 2002; Eschtruth and others 2006) where the following changes to forests have been documented: (1) a reduction of overstory canopy (Orwig and others 2008); (2) increases in light availability to the understory (Eschtruth and others 2006); (3) significant alterations of soil nitrogen cycling (Jenkins and others 1999); (4) accumulation of downed woody debris (Orwig and Foster 1998); and (5) decreased forest floor soil moisture (Orwig and others 2008).

It is well documented that the existence and composition of riparian forest strongly influences stream properties (Likens and others 1970). Indeed, in Delaware Water Gap National Recreation Area, Snyder and others (2002) and Ross and others (2003) found that hemlock dominance had a strong influence on species composition of aquatic invertebrates and fish; stream hydrology; and stream water temperature regimes. Although much research has focused on consequences of hemlock mortality on ecosystem processes in the northeastern and mid Atlantic United States, the impacts of the recent expansion of HWA into the southern Appalachians have received far less attention. In 2002, HWA was found within the borders of Great Smoky Mountains National Park (GSMNP) (Johnson and others 2005). In GSMNP, hemlocks commonly dominate riparian areas and cove forests near stream headwaters. The loss of hemlock from riparian forests is therefore likely to significantly alter riparian ecosystem properties.

The response of stream conditions to hemlock mortality will have both short- and long-term impacts. Short term impacts may be easily observed with careful monitoring of forests undergoing decline. However, predicting long term impacts is more difficult. Previous research indicates that hemlock stands will be replaced by hardwood stands (Orwig and Foster 1998; Eschtruth and others 2006), and, thus, we suggest that observations of similarly structured hardwood-dominated stream environments can serve as a predictor of the long-term changes in stream environments. Therefore, we selected paired watersheds with hemlockdominated riparian environments and topographically similar hardwood-dominated riparian environments. We then monitored these streams for one year, collecting data on stream temperature, $\mathrm{pH}$, nitrate concentrations, discharge, and available photosynthetic light. We addressed two main questions:

1. To what degree does hemlock-dominated riparian forest influence stream conditions and the adjacent riparian environment?

2. What long-term changes will occur with the eventual replacement of formerly hemlock-dominated forest by hardwood-dominated forest?

We conducted this research during 2005-2006 when HWA populations were present but hemlock decline had not yet been observed in our study sites. An additional goal of this work was to establish baseline data with which observed changes in future stream conditions could be compared to evaluate the magnitude of short-term changes.

\section{Methods}

Study Area

We examined first- and second-order headwater streams in Great Smoky Mountains National Park, located in the southern Appalachians along the border of North Carolina and Tennessee (GSMNP). GSMNP is one of the largest federally protected areas in the eastern United States, encompassing 212,000 ha (525,000 acres). Topography varies greatly and elevations range from $256 \mathrm{~m}$ (840 feet) to $2024 \mathrm{~m}$ (6643 feet). Eastern hemlock is one of the most common tree species in GSMNP, occurring as a dominant, co-dominant, or sub-canopy species across a broad range of forest community associations (Jenkins 2007). Hemlock is a dominant tree species in Southern Appalachian Acid Cove Forests and Southern Appalachian Eastern Hemlock Forest (Jenkins 2007). In addition to eastern hemlock, these forests typically contain Tulip Poplar (Liriodendron tulipifera), Black Birch (Betula lenta), Red Maple (Acer rubrum), and White Pine (Pinus strobes). The shrub layer of these forests is dominated by Rosebay Rhododendron (Rhododendron maximum) and Dog Hobble (Leucothoe fontanesiana). The herbaceous layer is typically sparse with low species richness, but includes Intermediate Wood Fern (Dryopteris intermedia), Downy Rattlesnake-Plantain (Goodyera pubescens), Partridgeberry (Mitchella repens), and Christmas Fern (Polystichum acrostichoides) (Jenkins 2007).

Hemlock-dominated forest is widespread throughout the Park, covering 13001 ha (3820 acres), and occurs along lower elevation streams and protected slopes (Jenkins 2007). GSMNP contains over $3200 \mathrm{~km}$ (2000 miles) of stream channels. High-gradient streams in GSMNP provide habitat for a diverse aquatic biota, including native brook trout (Salvelinus fontinalis) and 30 species of salamanders.

\section{Selecting Paired Watersheds}

To isolate the effect of riparian hemlock forest on stream conditions, we compared hemlock-dominated watersheds with hardwood-dominated watersheds. Due to the complexities of natural variation in landscapes, careful site selection is imperative in order to draw strong inferences from comparative analyses. We modified an existing GISbased site selection methodology (Young and others 2002) to minimize the influence of landscape variability. The 
overall goal of the site selection design was to select stream monitoring sites that isolate differences in stream conditions and water quality due to forest type with all other factors being as similar as possible.

We delineated first- and second-order streams and watersheds within GSMNP using a 10-meter digital elevation model (DEM) with a minimum catchment size of $100,000 \mathrm{~m}^{2}$. We then used GSMNP spatial data to identify watersheds that had been minimally disturbed by fire, development, or logging. From these watersheds, we selected 298 candidate watersheds all within the boundary of GSMNP. These watersheds ranged in size from 69 to 962 ha with an average size of 182 ha.

We then characterized the terrain of these watersheds by calculating terrain statistics across three spatial scales within each watershed (stream channel, a $100 \mathrm{~m}$ riparian buffer, and watershed-wide) (Table 1). We placed emphasis on the riparian buffer in order to effectively assess the direct influence of the terrain surrounding the streams. Across these scales, we calculated the following terrain variables to account for topographic differences among watersheds: terrain shape index; slope/aspect transformation index; and topographic radiation index (TRI). Terrain shape index is a measure of local convexity (positive value; ridge) or concavity (negative value; gorge) (McNab 1989). Slope/aspect transformation index is a continuous value from -1 to 1 , which indicates the degree to which the slope is facing north (1) or south $(-1)$ (Stage 1976). The topographic radiation index (TRI) is a measure of how much solar radiation an area should receive based on its aspect. A TRI value of zero indicates locations that are typically cool and wet while a value of one indicates locations that are typically hot and dry (Roberts and Cooper 1989).

We analyzed terrain statistics for each of the 298 candidate watersheds using a K-means Cluster Analysis classification. As a result, all watersheds were classified into five terrain classes.

We further controlled watershed selection for size, geological substrates, and atmospheric deposition. Underlying geology and atmospheric deposition have been found to influence stream chemistry in the Appalachians (Flum

Table 1 Spatial scales used for each terrain variable

\begin{tabular}{llll}
\hline Terrain variables & $\begin{array}{l}\text { Stream } \\
\text { channel }\end{array}$ & $\begin{array}{l}100 \text { meter } \\
\text { riparian buffer }\end{array}$ & $\begin{array}{l}\text { Entire } \\
\text { watershed }\end{array}$ \\
\hline Mean elevation & $\mathrm{X}$ & $\mathrm{X}$ & $\mathrm{X}$ \\
Range of elevation & $\mathrm{X}$ & $\mathrm{X}$ & \\
Mean slope & & $\mathrm{X}$ & \\
Terrain shape index & & $\mathrm{X}$ & \\
Slope/aspect transformation & & $\mathrm{X}$ & \\
Topographic radiation index & & $\mathrm{X}$ & \\
\hline
\end{tabular}

and Nodvin 1995; Zhi-Jun and others 2000). We classified watershed size as: (1) 69-183; (2) 184-299; and (3) 300962 hectares. Using geologic data from the National Park Service's legacy data, we lumped the 25 different classifications of underlying bedrock identified in the GSMNP geology database into sandstones and siltstones. We also chose to not include watersheds in this study that drain areas of shale-dominated Anakeesta Formation, which has the ability to yield sulphuric acid and significantly influence water chemistry (Flum and Nodvin 1995). We then created a model of atmospheric deposition for GSMNP based on elevation and forest type (Weathers and others 2000). We classified atmospheric deposition into five classes representing different levels of probable deposition from low to high.

We combined the terrain, watershed size, geology, and deposition variables into a GIS model to select pairs that minimized differences in these factors. We then used a Euclidean distance dissimilarity matrix to identify pairs such that one hemlock-dominated watershed was paired with a hardwood-dominated watershed. We defined hemlock-dominated watersheds as watersheds where canopy tree species of the entire riparian corridor (100 meter width) were more than $60 \%$ hemlock. We defined deciduous hardwood-dominated watersheds as watersheds where canopy tree species of the entire riparian corridor were less than $15 \%$ hemlock. Hardwood-dominated watersheds were composed of cove hardwood and northern hardwood species such as Tulip Poplar (Liriodendron tulipifera), Carolina Silverbell (Halesia tetraptera), Black Birch (Betula lenta), Red Maple (Acer rubrum), Yellow Birch (Betula alleghaniensis), and American Beech (Fagus grandifolia). We quantified hemlock and hardwood canopies using a detailed vegetation database of GSMNP developed by Welch and others (2002) which used photogrammetry and GIS techniques. In all, we identified and selected six pairs of geographically similar hemlock and hardwood-dominated watersheds that met field verification parameters of access, stream size, flow rates, and structure (Table 2).

Field Methods and Data Collection

\section{Water Quality Measures}

Within each of the 12 selected watersheds, we established a monitoring site approximately $20 \mathrm{~m}$ upstream of the watershed pourpoint and measured stream water temperature, $\mathrm{pH}$, and nitrate concentrations. We followed procedures outlined in the United States Geological Survey National Field Manual for the Collection of Water-Quality Data (USGS, variously dated, http://pubs.water.usgs.gov/ twri9A). We used Alpha Mach IBCod (c) data loggers to collect stream water temperature measurements at hourly 


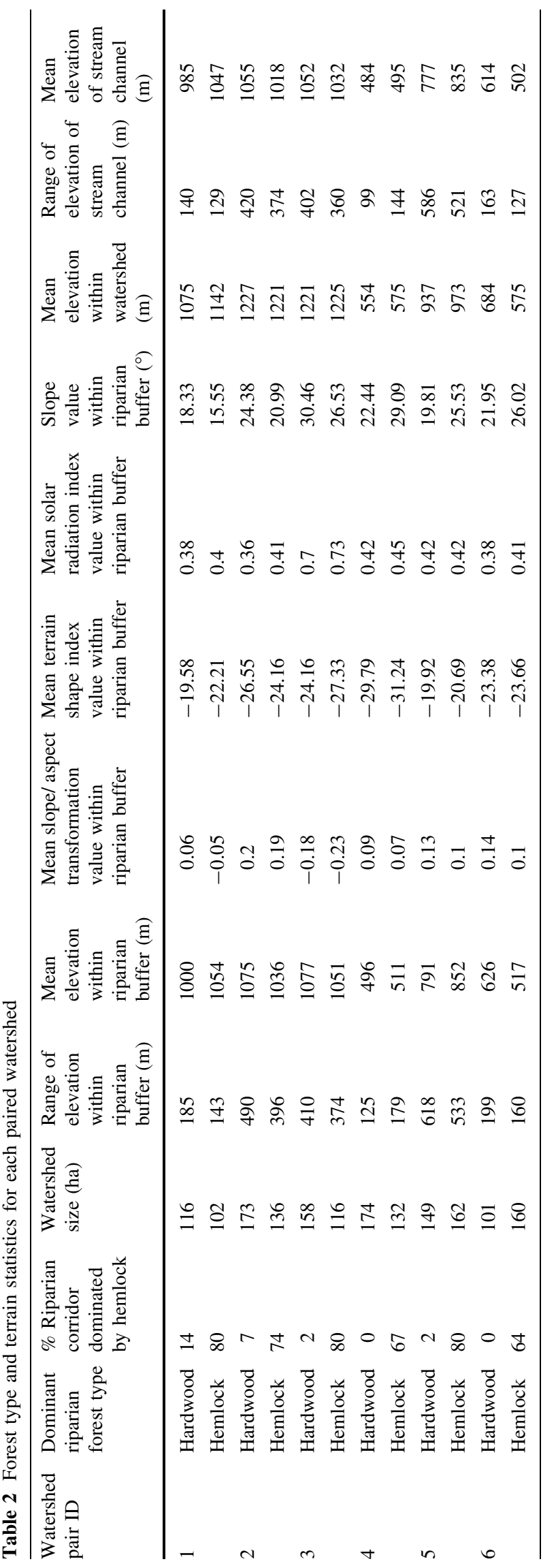

increments for 10 months (June 2005-March 2006). Data collection resulted in approximately 7500 data points per stream. We placed the temperature data loggers in stream riffle locations where perennial flow would be consistent. We visited each site every 30-60 days to download water temperature data from the data loggers and to collect additional water quality parameters. During each visit to study sites, we measured stream flow using a JDC Flowatch flow meter, $\mathrm{pH}$ using a Hach Sension $\mathrm{pH}$ meter, and collected stream water grab samples using $60 \mathrm{~mL}$ polyethylene bottles. We collected data from both the hemlock and the hardwood members of each pair either on the same day or on two consecutive days with similar weather conditions.

We analyzed each grab sample of water for stream water nitrate concentrations within $48 \mathrm{~h}$ of collection using a Hach DR/2500 Spectrophotometer. We used a Cadmium Reduction Method for detecting nitrate, which is outlined in Hach's DR/2500 Procedure Manual (Hach Company 2004). We implemented and conducted quality control procedures based on a Hach publication for quality control in laboratories (Martin 2002). These quality control procedures included using standard solutions, sample spikes, and sample replicates in order to check the accuracy of nitrate analysis.

\section{Photosynthetically Active Radiation}

In order to quantify the difference in insolation on the forest floor between hemlock and hardwood forest canopies, we measured photosynthetically active radiation (PAR) and foliar cover within riparian forest in a subsample of three of the six paired watersheds (3 hardwooddominated sites and 3 hemlock-dominated sites) once in August during leaf-on and once in January during leaf-off. Within each hardwood-dominated riparian forest site, we identified four forest composition types by visual assessment: hardwood canopy with minimal understory; hardwood canopy with dense deciduous hardwood understory; hardwood canopy with hemlock understory; and hardwood canopy with dense Rhododendron understory. Within each hemlock-dominated riparian forest site we visually identified two forest composition types by visual assessment: hemlock canopy with no significant understory; and hemlock canopy with dense Rhododendron understory. We established one linear transect parallel to the stream channel $50 \mathrm{~m}$ in length in each hardwood and hemlock forest type (i.e., four transects in each hardwood-dominated site and two transects in each hemlock-dominated site). PAR and foliar cover measurements were taken at $10 \mathrm{~m}$ increments along each $50 \mathrm{~m}$ transect culminating in 5 PAR and 5 foliar cover measurements per transect. All measurements were taken at a height of $1.4 \mathrm{~m}$ above the forest floor, beneath any understory foliage that was 
present. We then calculated an average PAR and foliar cover measurement for each forest type.

We measured PAR using a Sunfleck Ceptometer PAR meter, which measures PAR as micromoles of quanta per square meter per second $\left(\mathrm{mmol} \mathrm{m} \mathrm{m}^{-2} \mathrm{~s}^{-1}\right)$. A spherical densiometer was used to quantify foliar cover. Methodologies for using the PAR meter are outlined in Sunfleck Ceptometer Operator's Manual (Decagon Devices Inc. 1991); methods for using the Spherical Densiometer are in the Spherical Densiometer Instruction Sheet (Lemmon 1956).

\section{Data Analysis}

We tested for significant differences between means for each pair of hardwood- and hemlock-dominated sites for measured parameters including stream temperature, nitrate concentrations, discharge, and $\mathrm{pH}$. We used the Independent Samples T-Test for determining differences in means of nitrate concentrations, discharge, and $\mathrm{pH}$ (normally distributed) and the Kolmogorov-Smirnov $Z$ test for stream water temperatures (not normally distributed). We also tested for equal variance between each pair of hemlock and hardwood site using Levene's Test for Equality of Variances. We conducted statistical analysis with SPSS statistical software. In all cases, we used an $\alpha$-level of 0.05 to determine statistical significance.

Due to wildlife and human disturbance of temperature data loggers, there are periods of time when we were unable to obtain valid temperature data at some sites. In order to avoid the influence of these data gaps, we only used temperature data in our analyses that were consistently collected in both the hardwood- and hemlock-dominated sites within a pair.

\section{Results}

\section{Stream Water Temperature}

We found no consistent relationship between forest type and temperature regime (Table 3). Water temperatures varied, with some hardwood streams having statistically higher mean temperatures (Pairs 1, 5, and 6; $P=0.0095$, $0.0001,0.0001$ respectively), and some hemlock streams having statistically higher mean temperatures (Pairs 2, 3, and $4 ; P=0.0002,0.0031,0.0085)$. Although these differences were statistically significant, they were small (ranging from 0.02 to $0.53^{\circ} \mathrm{C}$ ). Strong diurnal fluctuations were observed in both hemlock- and hardwood-dominated streams, with no apparent differences in magnitude or pattern between the two forest types. We also found no consistent pattern of maximum temperatures or annual ranges of temperatures occurring with forest type.

\section{Stream Nitrate Concentrations}

Neither hemlock- nor hardwood-dominated streams had consistently higher nitrate concentrations among all pairs (Fig. 1). For each pair, we found equal variance and no significant difference in mean nitrate concentrations between hemlock- and hardwood-dominated streams. Nitrate concentrations in all streams ranged from 0.0023 to $0.1356 \mathrm{mg} / \mathrm{L} \mathrm{NO} \mathrm{N}_{3}-\mathrm{N}$ with an average of $0.0399 \mathrm{mg} / \mathrm{L}$ $\mathrm{NO}_{3}-\mathrm{N}$. Although differences were not significant, hardwood-dominated streams had higher nitrate concentrations in pairs 1 and $2(P=0.762$, and 0.984 , respectively), while hemlock-dominated streams had higher nitrate concentrations in pairs $3,4,5$, and $6(P=0.248,0.253,0.155$, and 0.07 , respectively).

Table 3 Stream parameters for paired hemlock and hardwood forests measured from June 2005 to March 2006

\begin{tabular}{llrrrr}
\hline Pair & Dominant forest & Temp $\left({ }^{\circ} \mathrm{C}\right)$ & Nitrate $(\mathrm{mg} / \mathrm{L}$ N03-N) & pH & Discharge $(\mathrm{m} 3 / \mathrm{s} / \mathrm{ha})$ \\
\hline 1 & Hemlock & $10.97 \pm 4.22$ & $0.009 \pm 0.0062$ & $6.84 \pm 0.0003$ & $0.0007 \pm 0.0912$ \\
& Hardwood & $11.11 \pm 4.99$ & $0.001 \pm 0.0041$ & $6.87 \pm 0.0008$ & $0.0011 \pm 0.0846$ \\
2 & Hemlock & $10 \pm 5.63$ & $0.111 \pm 0.0196$ & $6.89 \pm 0.0009$ & $0.001 \pm 0.0779$ \\
& Hardwood & $9.58 \pm 5.75$ & $0.113 \pm 0.0164$ & $6.87 \pm 0.0009$ & $0.0008 \pm 0.1023$ \\
3 & Hemlock & $10.05 \pm 4.68$ & $0.033 \pm 0.0105$ & $6.87 \pm 0.0005$ & $0.0008 \pm 0.0684$ \\
& Hardwood & $10.01 \pm 4.72$ & $0.026 \pm 0.0143$ & $6.92 \pm 0.0004$ & $0.0006 \pm 0.1055$ \\
4 & Hemlock & $12.11 \pm 5.85$ & $0.01 \pm 0.0019$ & $6.9 \pm 0.0003$ & $0.0004 \pm 0.0486$ \\
5 & Hardwood & $12.09 \pm 5.37$ & $0.01 \pm 0.0032$ & $6.81 \pm 0.0002$ & $0.0004 \pm 0.1598$ \\
& Hemlock & $10.9 \pm 5.22$ & $0.053 \pm 0.0052$ & $6.84 \pm 0.0004$ & $0.0005 \pm 0.0424$ \\
6 & Hardwood & $11.19 \pm 5.71$ & $0.05 \pm 0.0053$ & $6.88 \pm 0.0003$ & $0.0005 \pm 0.0635$ \\
& Hemlock & $13.69 \pm 4.78$ & $0.019 \pm 0.0034$ & $6.88 \pm 0.0002$ & $0.0003 \pm 0.0674$ \\
& Hardwood & $14.22 \pm 5.78$ & $0.016 \pm 0.0043$ & $6.85 \pm 0.0004$ & $0.0006 \pm 0.1817$ \\
\hline
\end{tabular}

Mean values plus or minus one standard deviation are included 


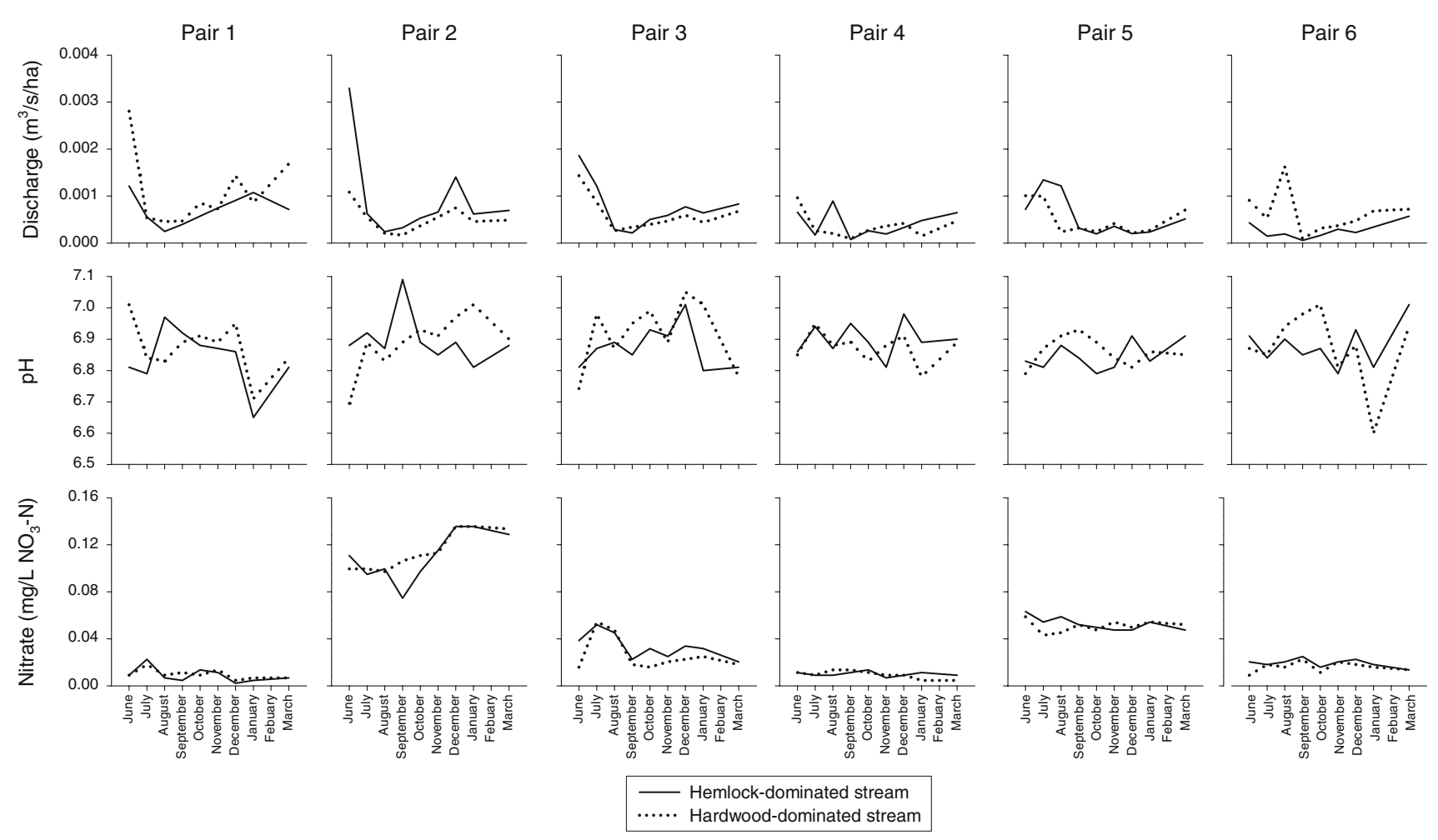

Fig. 1 Discharge, $\mathrm{pH}$, and Nitrate concentrations among six pairs of hemlock and hardwood-dominated streams

\section{Stream $p H$}

Stream $\mathrm{pH}$ values were also similar within pairs (Fig. 1). For each pair, we found equal variance and no significant difference in stream $\mathrm{pH}$ between hemlock- and hardwooddominated streams. Concentrations were all close to neutral (7.0); values ranged from 6.4 to 7.0, with an average of 6.87 for all streams. Neither hemlock- nor hardwooddominated streams had consistently higher $\mathrm{pH}$ among all pairs. Although differences were not significant, hardwooddominated streams had a higher $\mathrm{pH}$ in pairs 1,3 , and 5 ( $\mathrm{p}=0.501,0.484$, and 0.132 , respectively), while hemlock-dominated streams had a higher $\mathrm{pH}$ in pairs 2,4 , and 6 $(P=0.491,0.146$, and 0.752 , respectively $)$.

\section{Stream Discharge}

Stream discharge was also similar within pairs (Fig. 1). We found equal variance and no significant difference in mean stream discharge between hemlock- and hardwood-dominated streams. Mean discharge for all streams ranged from 0.0003 to $0.0011 \mathrm{~m}^{3} / \mathrm{s} / \mathrm{ha}$. Neither hemlock- nor hardwooddominated streams had consistently higher discharge among all pairs. Although differences were not significant, hardwood-dominated streams had a higher discharge in pairs $1,3,4$, and $6(P=0.226,0.844,0.856$, and 0.0 .155 , respectively), while hemlock-dominated streams had a higher discharge in pairs 2 and $5(P=0.917,0.618)$.

Photosynthetically Active Radiation and Foliar Cover

We found no significant difference in PAR $(P=0.6871)$ and foliar cover $(P=0.6443)$ between hemlock- and hardwood-dominated forest types during summer (leaf-on) conditions, but we did find a significant difference during winter (leaf-off) conditions $(P=0.0089,0.0292$, respectively). This difference can largely be attributed to differences in understory species composition among forest types, which we found to be a strong determinant of the light conditions of the forest interior (Fig. 2). In winter (leaf-off) conditions, when the influence of evergreen foliage on light conditions should be the strongest, we observed the lowest light conditions $\left(11 \mathrm{mmol} \mathrm{m}^{-2} \mathrm{~s}^{-1}\right)$ and the highest foliar cover $(83.36 \%)$ in hemlock-dominated forest with a dense Rhododendron understory. However, also in winter (leaf-off) conditions, we found similarly low light conditions $\left(27 \mathrm{mmol} \mathrm{m}^{-2} \mathrm{~s}^{-1}\right)$ and high foliar cover $(83.36 \%)$ in hardwood-dominated forest that also had a dense Rhododendron understory. In hardwood-dominated forest with minor understory, we found much higher light conditions $\left(378 \mathrm{mmol} \mathrm{m}^{-2} \mathrm{~s}^{-1}\right)$ and lower foliar cover $(19 \%)$. These results suggest that when Rhododendron is 
Fig. 2 PAR (a) and Canopy Cover (b) for four different hardwood-dominated riparian forest types and two different hemlock-dominated riparian forest types. PAR values $\left(\mathrm{mmol} \mathrm{m}{ }^{-2} \mathrm{~s}^{-1}\right)$ indicate the amount of photosynthetically active radiation received in the forest interior. Canopy cover values indicate the percentage of overhead sky obscured by plant material (a)

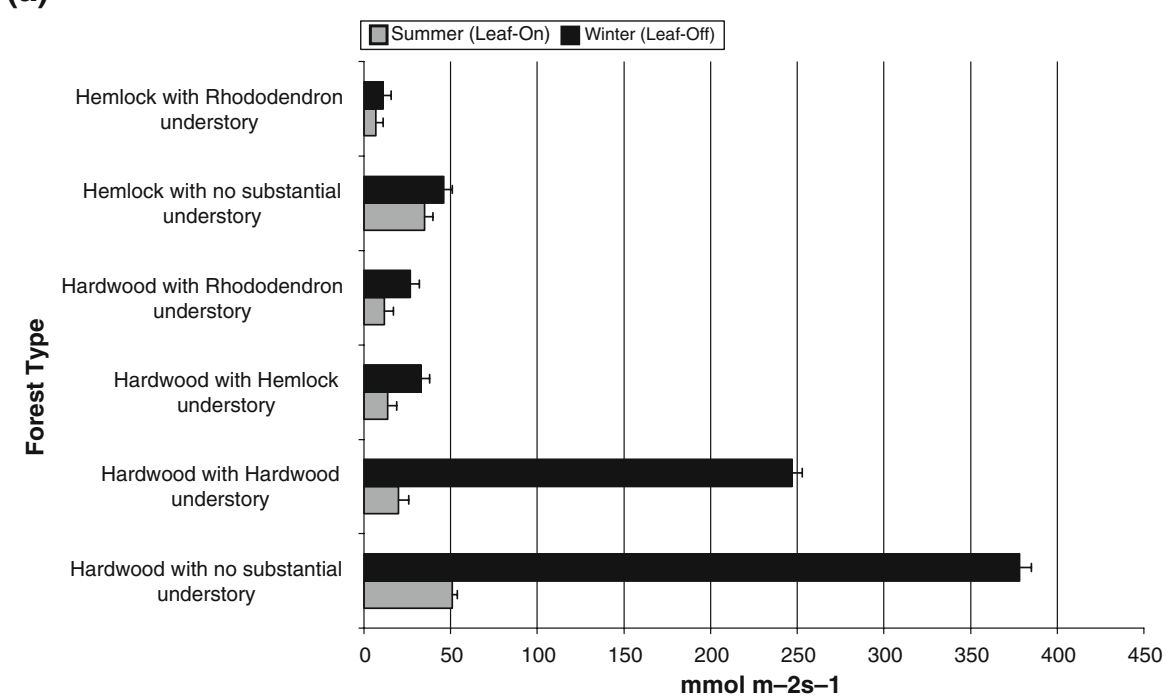

(b)

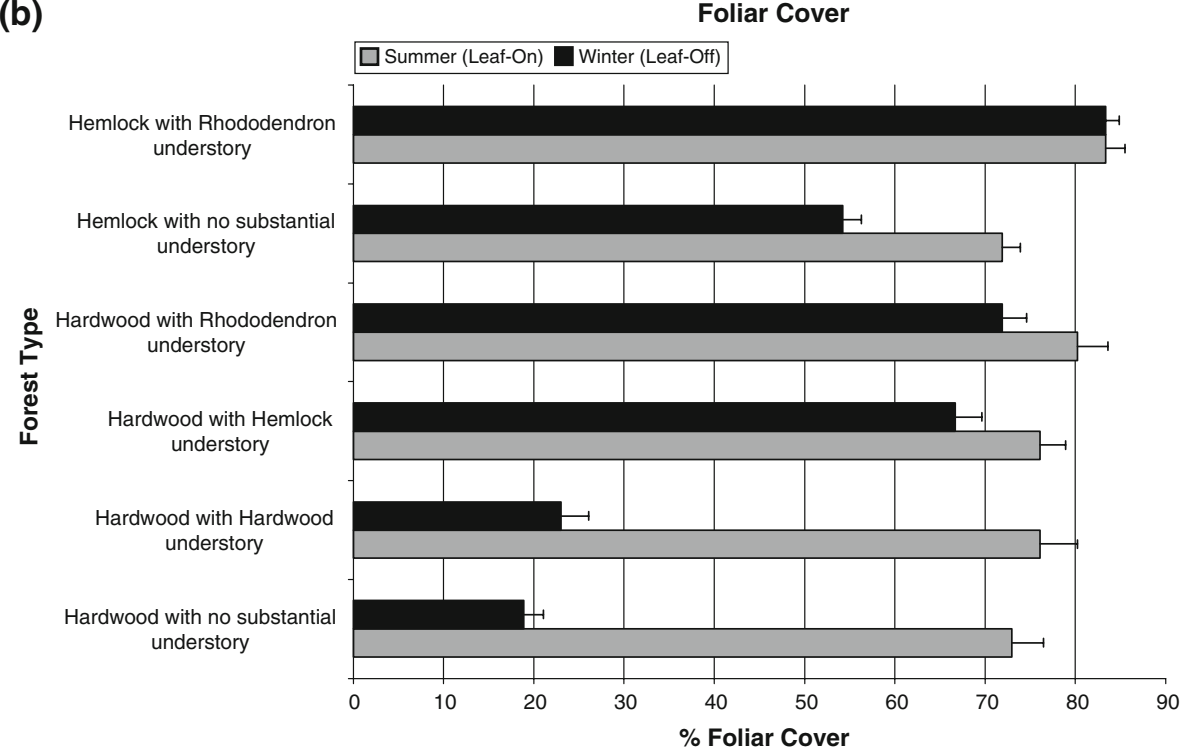

abundant in the understory, the magnitude of difference in forest floor light conditions between hemlock- and hardwood-dominated forest types is diminished.

\section{Discussion}

We found that stream nitrate concentrations, $\mathrm{pH}$, hydrology, and water temperatures are similar between hemlockand hardwood-dominated streams in GSMNP. These results suggest that if a riparian hemlock forest is eventually able to successfully make the transition to a riparian hardwood forest with similar composition as those observed in this study, there will be no significant difference in stream nitrate concentrations, water temperatures, $\mathrm{pH}$, or discharge.

\section{Water Temperature}

The presence of hemlock or hardwood riparian forest does not appear to exert a strong, consistent signal on thermal regimes of headwater streams in GSMNP. These results suggest that other landscape variables, such as the influence of groundwater or understory species, may exert more control on stream temperatures than differences between hemlock and hardwood forest types in GSMNP.

The presence of dense Rhododendron thickets in the understory of riparian hemlock and hardwood forests may have a significant impact on thermal and hydrologic regimes of headwater streams. We found the lowest levels of PAR and the highest foliar cover measurements beneath Rhododendron. Additionally, Rhododendron often is associated with deep, slowly decomposing litter on the forest floor, 
similar to the litter beneath hemlocks (Romancier 1971). Since Rhododendron occurs almost ubiquitously as a dense understory species in both hemlock and hardwood-dominated riparian forests in GSMNP, its presence may dampen the otherwise unique influences of hemlock and hardwood forest types on riparian environmental conditions.

Snyder and others (2002) found that in Delaware Water Gap National Recreation Area, NJ, hemlock-dominated streams had more stable thermal and hydrologic regimes than hardwood-dominated streams. The contrasting results can possibly be attributed to differences in riparian hemlock forest composition between GSMNP and DWGNRA study sites. Mahan and others (2004) report hemlock percent basal area ranging from 32 to 77 in surveyed hemlock stands in DWGNRA. In contrast, Kincaid (2007) documented basal areas of hemlock stands in GSMNP ranging from 19.9-72.4. Additionally, Kincaid found that riparian hemlock stands occurring in GSMNP are species-rich and contain dense understories of Rhododendron (Joshua Kincaid, personal communication, October, 2008, Shenandoah University). Unfortunately differences between mid-Atlantic and southern Appalachian riparian hemlock stands have not been directly examined. However, it is possible that riparian hemlock forests in the southern Appalachians may be more species rich and contain more Rhododendron cover than riparian hemlock forest in the mid-Atlantic (personal observation).

\section{Short-Term and Long-Term Impacts of Hemlock Mortality}

\section{Immediate, Short-Term Impacts of Hemlock Mortality}

Past research has shown that short-term impacts to stream conditions from hemlock mortality and other forest disturbances can be severe (e.g., Orwig and Foster 1998; Jenkins and others 1999; Orwig and others 2002; Eschtruth and others 2006; Orwig and others 2008). However, less is known about the type and extent of immediate impacts to water quality and riparian conditions caused by hemlock mortality. Immediate impacts to stream conditions caused by hemlock mortality may be similar to the documented impacts to stream conditions from other types of disturbances to riparian forest. Alterations to stream solute concentrations (e.g., Likens and others 1970; Lewis and Likens 2007) and stream temperatures (e.g., Burton and Likens 1973; Johnson and Jones 2000) have been observed in disturbed riparian forest. The severity of these initial impacts will depend on the size of and composition of riparian hemlock stands and the rate and timing of decline and mortality. If hemlock mortality occurs in a large, monospecific riparian hemlock stand, we hypothesize that somewhat severe localized impacts to water quality may occur.
The recovery from these initial impacts will ultimately depend on the rate at which undisturbed species and replacement species can fill the empty niche left by the declining and standing dead hemlocks. Observations from other forest disturbances document that elevated stream nitrate concentrations returned to pre-disturbance levels five to ten years after forest harvesting (Bormann and Likens 1979; Townsend and others 2004) and two years after insect-induced hardwood defoliation (Lewis and Likens 2007). Extensive mortality of Fraser firs (Abies fraseri) in the southern Appalachians occurred in the $1980 \mathrm{~s}$ due in part to the infestation of the exotic Balsam Woolly Adelgid (Jenkins 2003). Robinson and others (2004) suggest that as regenerating Fraser firs began to replace standing dead mature Fraser firs in GSMNP, elevated stream nitrate concentrations decreased significantly.

\section{Eventual, Long-Term Impacts from Hemlock Mortality}

We found that stream nitrate concentrations, $\mathrm{pH}$, hydrology, and water temperatures are similar between hemlockand hardwood-dominated streams in GSMNP. However, these results refer to watershed-scale impacts; localized impacts may be more severe. For example, some headwater streams have deep pools that are currently located beneath dense hemlock canopy and may be a refuge for biota seeking the shaded cooler water during warm summer months.

Our results suggest that if a riparian hemlock forest is eventually able to successfully make the transition to a riparian hardwood forest with similar composition as those observed in this study, there will be no significant difference in stream nitrate concentrations, water temperatures, $\mathrm{pH}$, or discharge. However, Rhododendron has two significant attributes that could potentially prevent an intact hardwood-dominated riparian forest from replacing the formerly hemlock-dominated riparian forest in the southern Appalachians: (1) Rhododendron grows vigorously in disturbed areas (McGee and Smith 1967; Dobbs and Parker 2004), and (2) Rhododendron limits the regeneration of hardwood tree species (Clinton and Vose 2000; Nilsen and others 2001; Lei and others 2002; Hille Ris Lambers and Clark 2003).

With the disturbance to riparian forest canopy caused by hemlock mortality, it is possible that dense thickets of Rhododendron could expand along formerly hemlockdominated riparian corridors and prevent the recruitment and colonization of hardwood canopy-tree seedlings. Additionally, with the loss of riparian hemlock, it is possible that dense Rhododendron thickets without overstory tree species may become more prevalent in the riparian forest of the southern Appalachians. Additional research on the influence of Rhododendron thickets on riparian 
environmental conditions would contribute to a better understanding of the potential future of currently hemlockdominated riparian forest in GSMNP.

\section{Forest Management Implications}

We suggest that riparian hemlock stands should be considered as priority sites for the implementation of HWA control strategies in order to help minimize potential shortterm impacts to riparian environmental conditions. Efforts should be focused on large pure-species riparian hemlock stands that will have the greatest immediate impact to stream conditions.

In locations where hemlock mortality has occurred, management agencies should investigate opportunities to encourage the establishment of native hardwood canopy species, particularly in locations with dense rhododendron, in order to help establish an intact riparian vegetation cover to replace hemlock. An intact riparian vegetative cover will intercept solar radiation, reducing energy input to stream water surfaces, and will take up nutrients, reducing the levels of nitrate that will enter stream water.

Due to Rhododendron's ability to limit the regeneration of hardwood species, it may be necessary for management agencies to actively encourage hardwood establishment in riparian locations with dense rhododendron. Vandermast and Lear (2002) suggest introducing periodic fire into riparian forests in the southern Appalachians in order to control Rhododendron expansion and to help encourage hardwood canopy tree regeneration. While fire introduction may suppress the establishment of Rhododendron thickets, it may also lead to further increases in nutrient export to stream water and therefore should be used with caution. The mechanical removal of Rhododendron has proved somewhat unsuccessful and should also be used with caution. Clinton and Vose (2000) document the development of extremely high densities of Rhododendron after only a few years following mechanical removal.

\section{Conclusion}

This study specifically addresses the impacts to stream conditions from hemlock mortality and suggests that in the long term in GSMNP these may be minimal if hardwood forests are able to successfully replace hemlock forests. There are, of course, limitations to our study that may provide insight for new research direction.

First, inferences from this research are limited by the duration of the study and the sample size. Although we found no clear, consistent pattern of hemlock or hardwood riparian forest being associated with particular stream conditions, a pattern could emerge from a larger sample size monitored over a longer period of time. However, the magnitude and variation in stream chemistry conditions that we found here are comparable with stream conditions that occur with hardwood- and hemlock-dominated headwater streams throughout GSMNP. Thus, a larger sample size may not have yielded different results. However, the results presented in this article are a good representation of the stream conditions that occur with hardwood- and hemlock-dominated headwater streams in GSMNP, and we are confident that a larger sample size would yield similar results.

In addition, it is important to note that we do not address impacts from hemlock mortality on aesthetics, recreation, other flora, or fauna, all of which could be substantially affected by the loss of hemlock from eastern forests. Additional studies investigating impacts from hemlock mortality on specific flora and fauna are needed. In particular, determining if there is a relationship in the southern Appalachians between riparian hemlock dominance and aquatic fauna, such as fish and macroinvertebrate communities, is essential.

This study focuses on the influence of hemlock overstory canopy on riparian conditions and the consequences of this loss. However, understory species composition may be equally or more important in influencing riparian conditions. We found low PAR and high foliar cover in forests with understory species dominated by hemlock. Additional research is needed to determine whether understory hemlock in both hemlock and hardwood dominated forests exerts significant influence on riparian systems and what the consequences of the loss of hemlock as an understory species would be. We also note that rhododendron presence in the understory may be an important influence on riparian conditions.

This article only examines the suite of parameters measured in this study (temperature, $\mathrm{pH}$, nitrate-nitrogen, discharge, available photosynthetic light). However, there are clearly other variables that may be equally as important in affecting riparian ecosystem processes and structure. The understanding of hemlock-dominated riparian systems in GSMNP could be further improved by investigations of parameters such as dissolved oxygen, aquatic invertebrate communities, and energy cycling, for example.

Finally, our results provide baseline data for low- to middle-elevation headwater streams before the onset of HWA-induced hemlock mortality in GSMNP. This baseline data can be used in the future to track the magnitudes of changes in riparian environmental conditions that occur with hemlock decline and hemlock mortality. Indeed, the watersheds described here are currently under attack by HWA (personal observation). Repeated sampling may provide managers with a better understanding about how riparian conditions may change over time with the onset of 
HWA and at which stage forests should be targeted for the most intensive intervention.

Acknowledgments The authors thank the Tennessee Valley Authority and the Great Smoky Mountains Conservation Association for funding this research. We thank Dennis Yankee, Susan Sutherland, and Alan Mayes at the Tennessee Valley Authority and Carol Harden at the University of Tennessee for their interest and guidance with this research. Additionally, we thank Amy Concillio and Justin Hart for valuable suggestions on the manuscript.

Open Access This article is distributed under the terms of the Creative Commons Attribution Noncommercial License which permits any noncommercial use, distribution, and reproduction in any medium, provided the original author(s) and source are credited.

\section{References}

Anagnostakis SL (1987) Chestnut blight: the classical problem of an introduced pathogen. Mycologia 79(1):23-37

Bormann F, Likens G (1979) Pattern and process in a forested ecosystem. Springer, New York, 253 pp

Burton TM, Likens GE (1973) The effect of strip-cutting on stream temperatures in the Hubbard Brook experimental Forest, New Hampshire. Bioscience 23(7):433-435

Castello JD, Leopold DJ, Smallidge PJ (1995) Pathogens, and processes in forest ecosystems. Bioscience 45(1):16-24

Clinton B, Vose J (2000) Effects of Rhododendron maximum L. on Acer rubrum L. seedling establishment. Castanea 61:38-45

Decagon Devices Inc (1991) Sunfleck ceptometer operator's manual. Decagon Services Inc., Pullman, 77 pp

Dobbs M, Parker A (2004) Evergreen understory dynamics in Coweeta Forest, North Carolina. Physical Geography 25(6):481-498

Ellison A, Bank M, Clinton B, Colburn E, Elliott K, Ford C, Foster D, Kloeppel B, Knoepp D, Lovett G, Mohan J, Orwig D, Rodensouse N, Sobezak W, Stinson K, Stone J, Swan C, Thompson J, Van Holle B, Webser J (2005) Loss of foundation species: consequences for the structure and dynamics of forested ecosystems. Frontiers in Ecology and the Environment 3(9):479-486

Eschtruth AK, Cleavitt NL, Battles JJ, Evans RA, Fahey TJ (2006) Vegetation dynamics in declining eastern hemlock stands: 9 years of forest response to hemlock woolly adelgid infestation. Canadian Journal of Forest Research 36:1435-1450

Flum T, Nodvin SC (1995) Factors affecting streamwater chemistry in the Great Smoky Mountains, USA. Water, Air, and Soil Pollution 85:1707-1712

Hach Company (2004) DR 2400 spectrophotometer procedure manual. Hach Company, Loveland, 620 pp

Hille Ris Lambers J, Clark J (2003) Effects of dispersal, shrubs, and density-dependent mortality on tree seed and seedling distributions. Canadian Journal of Forest Research 33(5):783-795

Hollingsworth RG, Hain FP (1991) Balsam woolly adelgid (Homoptera: Adelgidae) and spruce-fir decline in the southern Appalachians: assessing pest reliance in a damaged ecosystem. The Florida Entomologist 74(2):179-187

Houston DR (1994) Major new tree disease epidemics: Beech bark disease. Annual Review of Phytopathology 32:75-87

Jenkins JC, Aber JD, Canham CD (1999) Hemlock woolly adelgid impacts on community structure and $\mathrm{N}$ cycling rates in eastern hemlock forests. Canadian Journal of Forest Research 19:630-645
Jenkins MA (2003) Impact of the balsam woolly adelgid (Adelges piceae Ratz.) on an Abies fraseri dominated stand near the summit of Mout LeCont, Tennessee. Castanea 68:109-118

Jenkins MA (2007) Vegetation communities of Great Smoky Mountains National Park. Southeastern Naturalist 1:35-56

Johnson SL, Jones JA (2000) Stream temperature responses to forest harvest and debris flows in western Cascades, Oregon. Canadian Journal Fisheries and Aquatic Sciences 57(Suppl 2):30-39

Johnson KS, Taylor G, Remaley T (2005) Managing hemlock woolly adelgid and balsam woolly adelgid in Great Smoky Mountains National Park. In: Third symposium on hemlock woolly adelgid in the Eastern United States. Forest Health Technology Enterprise Team, Morgantown, WV, USDA Forest Service, FHTET2005-01, $384 \mathrm{pp}$

Kincaid JA (2007) Compositional and environmental characteristics of Tsuga Canadensis (L.) Carr. forests in the southern Appalachian Mountains, USA. Journal of the Torrey Botanical Society 134(4):479-488

Lei T, Semones S, Walker J, Clinton B, Nilsen E (2002) Effects of Rhododendron maximum thickets on tree seed dispersal, seedling morphology, and survivorship. International Journal of Plant Sciences 163(6):991-1000

Lemmon P (1956) A spherical densiometer for estimating overstory density. Forest Science 2(1):314-320

Lewis GP, Likens GE (2007) Changes in stream chemistry associated with insect defoliation in a Pennsylvania hemlock-hardwoods forest. Forest Ecology and Management 238:199-211

Liebhold AM, Macdonald WL, Bergdahl D, Mastro VC (1995) Invasion by exotic forest pests: a threat to forest ecosystmes. Forest Science Monographs 30:49

Likens GE, Bormann FH, Johnson NM, Fisher DW, Pierce RS (1970) Effects of forest cutting and herbicide treatment on nutrient budgets in the Hubbard Brook watershed-ecosystem. Ecological Monograph 40(1):23-47

Mack RN, Simberloff D, Lonsdale WM, Evans H, Clout M, Bazzaz FA (2000) Biotic invasions: causes, epidemiology, global consequences, and control. Ecological Applications 10(3):689710

Mahan C, Sullivan K, Black B, Kim K, Yahner R (2004) Overstory tree composition of hemlock stands threatened by the hemlock woolly adelgid at Delaware Water Gap National Recreation Area. Castanea 69(1):30-37

Martin B (2002) An introduction to standards and quality control in the laboratory. Hach Company, Loveland, $40 \mathrm{pp}$

McClure MS (1991) Density-dependent feedback and populationcycles in Adelges-Tsugae (Homoptera, Adelgidae) on Tsuga canadensis. Environmental Entomology 20(1):258-264

McGee C, Smith R (1967) Undisturbed rhododendron thickets are not spreading. Journal of Forestry 65:334-336

McNab H (1989) Terrain shape index; quantifying effect of minor landforms on tree height. Forest Science 35(1):91-104

Nilsen E, Clinton B, Lei T, Miller O, Semones S, Walker J (2001) Does Rhododendron maximum L. (Ericaceae) reduce the availability of resources above and belowground for canopy tree seedlings? American Midland Naturalist 145:325-343

Orwig DA, Foster DR (1998) Forest response to the introduced hemlock woolly adelgid in southern New England, USA. Journal of the Torrey Botanical Society 125(1):60-73

Orwig DA, Foster DR, Mausel DL (2002) Landscape patterns of hemlock decline in New England due to the introduced hemlock woolly adelgid. Journal of Biogeography 29:1475-1487

Orwig DA, Cobb RC, D'Amato AW, Kizlinski ML, Foster DR (2008) Multi-year ecosystem response to hemlock woolly adelgid infestation in southern New England forests. Canadian Journal of Forest Research 38:834-843 
Roberts D, Cooper S (1989) Forest classification and inventory system using Landsat, digital terrain, and ground sample data. Thirteenth international symposium on remote sensing of environment. Environmental Research Institute of Michigan, Ann Arbor, pp 1541-1557

Robinson B, Wood M, Smoot J, Moore S (2004) Parametric modeling of water quality and sampling strategy in a high-altitude Appalachian stream. Journal of Hydrology 287:62-73

Romancier R (1971) Combining fire and chemicals for the control of Rhododendron thickets. USDA Forest Service Research Note SE-149, 7 pp

Ross RM, Bennett RM, Snyder CD, Young JA, Smith DR, Lemarie DP (2003) Influence of eastern hemlock (Tsuga candensis L.) on fish community structure and function in headwater streams of the Delaware River basin. Ecology of Freshwater Fish 12:60-65

Snyder CD, Young JA, Lemarie DP, Smith DR (2002) Influence of eastern hemlock (Tsuga Canadensis) forests on aquatic invertebrate assemblages in headwater streams. Canadian Journal of Fisheries and Aquatic Sciences 59:262-275

Stage A (1976) An expression of the effects of aspect, slope, and habitat type on tree growth. Forest Science 22(3):457-460

Townsend P, Eshleman K, Welcker C (2004) Remote sensing of gypsy moth defoliation to assess variations in stream nitrogen concentrations. Ecological Applications 14(2):504-516

U.S. Geological Survey (variously dated) National field manual for the collection of water-quality data. U.S. Geological Survey
Techniques of Water-Resources Investigations, book 9, chaps. A1-A9. http://pubs.water.usgs.gov/twri9A

Vandermast D, Lear D (2002) Riparian vegetation in the southern Appalachian mountains (USA) following chestnut blight. Forest Ecology and Management 155:97-106

Vitousek PM, DAntonio CM, Loope LL, Westbrooks R (1996) Biological invasions as global environmental change. American Scientist 84(5):468-478

Vitousek PM, Mooney HA, Lubchenco J, Melillo J (1997) Human domination of earth's ecosystems. Science 277:494-499

Weathers K, Lovett G, Likens G, Lathrop R (2000) The effect of landscape features on deposition to Hunter Mountain, Catskill Mountains, New York. Ecological Applications 10:528-540

Welch R, Madden M, Jordan T (2002) Photogrammetric and GIS techniques for the development of vegetation databases of mountainous areas: Great Smoky Mountains National Park. ISPRS Journal of Photogrammetry and Remote Sensing 57:5368

Young JA, Smith DR, Snder CD, Lemarie DP (2002) A terrain based paired-site sampling design to assess biodiversity losses from eastern hemlock decline. Environmental Monitoring and Assessment 76:167-183

Zhi-Jun L, Weller D, Correll D, Jordan T (2000) Effects of land cover and geology on stream chemistry in watersheds of Chesapeake Bay. Journal of the American Water Resources Association 36(6):1349-1365 